\title{
Postcards
}

Sciendo

10.2478/abcsj-2021-0021

\section{Homes for Canadians (II)}

\author{
DAVID BRIAN HOWARD \\ NSCAD University, Canada
}

\begin{abstract}
According to Giorgio Agamben, the Greek term for 'habitual dwelling place,' or 'habit,' is ethos. The rise to prominence in the twentieth century of the modern idea of the suburb, or 'suburbia,' held open the door to the potential realization of the American (and Canadian) dream ethos of universal home ownership. The tantalizing appeal of a the ideal of 'home' and 'homeland' have become key terms in the Post World War Two pursuit of a mode of 'dwelling' linked to consumer capitalism. Yet for Frankfurt School critics such as Theodor W. Adorno, the pursuit of this suburban ideal induced a deep sense of ennui such that to feel 'at home' in such a suburban environment challenged the very foundations of the dwelling place of Western civilization. "It is part of morality," Adorno concluded in his book, Minima Moralia, "not to be at home in one's home." This text is an exercise in examining this question of 'dwelling' and 'home' through an allegorical poetical focus (drawn from Walter Benjamin and Charles Baudelaire) focusing on a newly completed suburb in the Canadian city of Halifax, Nova Scotia.
\end{abstract}

Keywords: Suburbia, Dwelling, Home, Utopia, Dystopia, Flâneur, Modernité, Memory, History, the Body, Chiasmus, Ruins, Ephemeral, the Allegorical

"Despite its enduring idealization as a 'special, still sacred, quasi-religious and in fact almost sacred space' - as, for instance, in the 'ontological dignity' granted it by thinkers like Gaston Bachelard - the putatively 
exceptional space of the home provides the means for social and political reproduction precisely because of its seeming exclusion from these public zones of activity. Discussing the shift from a pre-capitalist monumentality, serving to integrate a disparate social multiplicity, to the simultaneously fragmented and naturalized genitality of the family unit under capital, Lefebvre writes,

Familial space, linked to naturalness through genitality, is the guarantor of meaning as well as of social (spatial) practice. Shattered by a host of separations and segregations, social unity is able to reconstitute itself at the level of the family unit, for the purpose of, and by means of, generalized reproduction. The reproduction of production relations continues apace amid (and on the basis of) the destruction of social bonds to the extent that the symbolic space of 'familiarity' (family life, everyday life), the only such space to be appropriated, continues to hold sway.

The home is thus foremost among producers of abstract space, at once the site "where contradictions evolve and which they tear apart, and, lastly, the means whereby they are smothered and replaced by an appearance of consistency.",

(Giorgio Agamben, Homo Sacer, qtd. in Eric D. Smith, Globalization, Utopia, and Postcolonial Science Fiction: New Maps of Hope. London and New York, NY: Palgrave Macmillan, 2012: 156.)

"Catachresis, as the middle, is here also a 'between,' a syncategorem: an interval that is neither purely semantic nor purely syntactic; a spacing."

(Peter Mahon, Imagining Joyce and Derrida: Between Finnegan's Wake and Glas. Toronto, Buffalo, and London: University of Toronto Press, 2007: 43.)

"His laughter then will burst out, directed toward a return which no longer will have the form of the metaphysical repetition of humanism, nor, doubtless, 'beyond' metaphysics, the form of the memorial or a guarding 
of the meaning of Being, the form of the house and of the truth of Being. He will dance, outside the house, the active Vergeslichkeit, the "active forgetting" and the cruel (grausam) feast of which [Nietzsche's] Genealogy of Morals speaks."

(Richard J. Bernstein, The New Constellation: The Ethical-Political Horizons of Modernity/ Postmodernity. Cambridge, MA: The MIT Press, 1994: 3.)

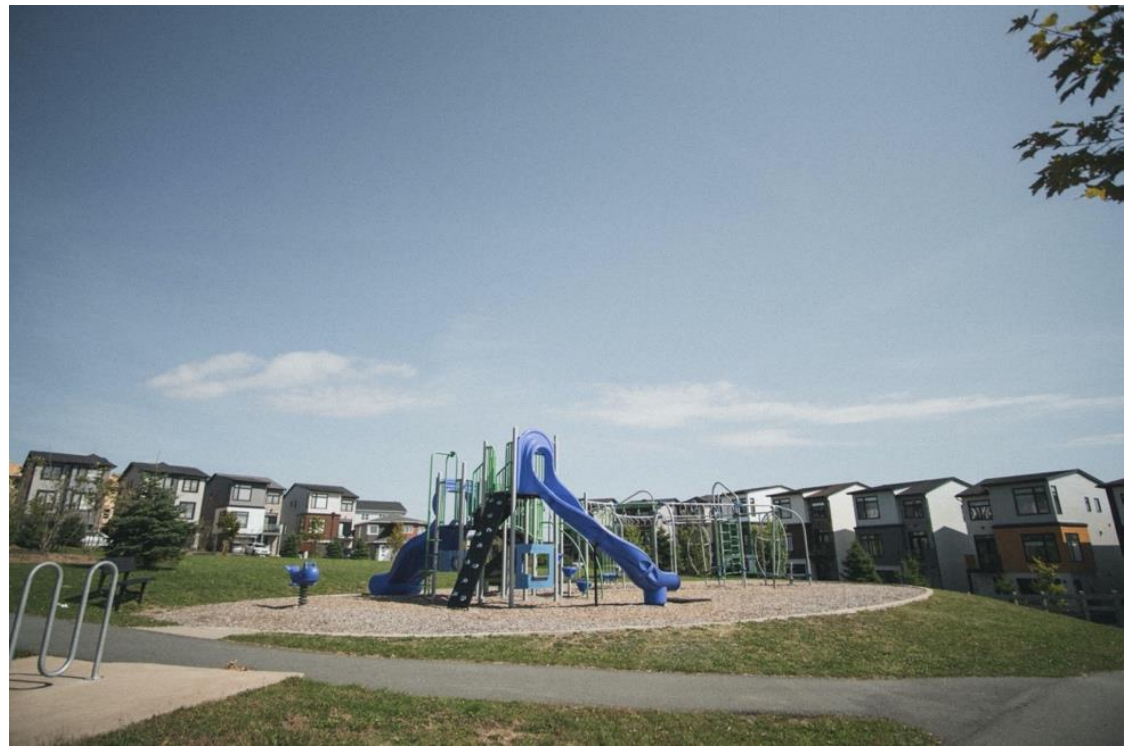

Geoffrey Howard, The Village at Long Lake, Halifax, Nova Scotia, Canada. (2020) Digital Photograph.

"Just so, the $\mathrm{X}$ of a chiasmus crosses at its center point, but opens in every direction, onto a surrounding void."

(Ross Chambers, An Atmospherics of the City: Baudelaire and the Poetics of Noise. New York, NY: Fordham University Press, 2015: 88.) 
"All cities are affected by the strength and motion of sunlight. 'What slice of the sun does your building have?' Louis Kahn asked, a question asked by every right-thinking architect, whether white cuboid villas were built to reflect the light or skyscrapers designed to minimize the shadow chasms between them. The pragmatic functional approach has encouraged buildings as variant as Maxwell Fry's Sun House and the Taj Mahal to be built dawn-facing or to maximize the exposure to the sun's arc. In Arthur Radebaugh's optimistically entitled comic strip, Closer Than We Think (1959), 'Don't be surprised if many of tomorrow's homes are built on turntables. They would slowly pivot all day long to receive maximum benefit from the health-giving sun ray and ensure heat in winter."'

(Darran Anderson, Imaginary Cities: A Tour of Dream Cities, Nightmare Cities, and Everywhere in Between. Chicago, IL: The University of Chicago Press, 2015: 65.)

"Suburban houses and 'new towns' came close to the lowest possible threshold of sociability - the point beyond which survival would be impossible because all social life would have disappeared. Internal and invisible boundaries began to divide a space that nevertheless remained in thrall to a global strategy and a single power. These boundaries did not merely separate levels - local, regional, national and worldwide. They also separated zones where people were supposed to be reduced to their 'simplest expression', to their 'lowest common denominator', from zones where people could spread out in comfort and enjoy those essential luxuries, time and space, to the full. As a matter of fact, 'boundaries' is too weak a word here, and it obscures the essential point; it would be more accurate to speak of fracture lines revealing true-invisible yet highly irregular - contours of 'real' social space lying beneath its homogenous surface."

(Henri Lefebvre (Donald Nicholson-Smith, Trans.), The Production of Space. Hoboken, NJ: Wiley-Blackwell, 1992: 316-7.) 
"I feel that suburbia, which is generally regarded as a place where not that much happens, is in fact more crucial in terms of social change than people realize. Changing lifestyles, changes in social consciousness - they are much more apparent in a place like this."

(J. G. Ballard, "Publishers Weekly" (1998), in V. Vale \& Mike Ryan, Eds., J.G. Ballard: Quotes: Does the Future Have a Future? San Francisco, CA: RE/Search Publications, 2005: 200.)

"I tried to find my way in and out of this labyrinth without asking anyone, again only directing myself by the points of the compass. Finally, one does disentangle oneself, but it is an incredible maze, and my method, which is to acquaint myself with it directly through my senses, is the best."

(Goethe's Italian Journey, qtd. in John Zilcosky, "Sebald's Travels: The Impossibility of Getting Lost," in J.J. Long and Anne Whitehead, W.G. Sebald: A Companion. Seattle: University of Washington Press, 2004: 103.)

"The mundus: a sacred or accursed place in the middle of the Italiot township. A pit, originally - a dust hole, a public rubbish dump. Into it were cast trash and filth of every kind, along with those condemned to death, and every newborn baby whose father declined to 'raise; it... A pit, then, 'deep' above all in meaning. It connected the city; the space above the ground, land-as-soil and land-as-territory, to the hidden, clandestine, subterranean spaces which were those of fertility and death, of the beginning and the end, of birth and burial... The pit was also a passageway through which dead souls could return to the bosom of the earth and tombs, vagina and nurturing earth-as-mother, dark corridor emerging from the depths, cavern opening to the light, estuary of hidden forces and mouth of the realm of shadow, the mundus terrified as it glorified. In its ambiguity it encompassed the greatest fondness and the 
greatest purity, life and death, fertility and destruction, horror and fascination."

(Henri Lefebvre, qtd. in Brian Jarvis, Postmodern Geographies: The Geographical Imagination in Contemporary American Cultures. New York: St. Martin's Press, 1998: 192.)

"He tries to leave the forest by going, in what he believes to be a straight line, towards his mother's house. In other words, he attempts to construct his present as the beginning of a linear narrative of time, a movement towards a distinct future end. But he only succeeds in going in a circle. Then, he deliberately tried to go in a circle, as does irony, and ends up going in a straight line towards his mother's house... Only irony can open up the possibility of allegory at this point of his journey."

(James H. Reid, Proust, Beckett, and Narration. Cambridge: Cambridge University Press, 2003: 95.)

"Cancelations, variants, erasures, marginal notes, stray marks and blanks that mark the site of repression and are cultural "memories in disguise."”

(David Clippinger, "Between the Gaps, the Silence and the Rubble: Susan Howe, Rosemarie Waldrop, and (Another) Pound Era," Denver Quarterly, 36.1-2, 2011: 189-205.)

"Walking is the best way to explore and exploit the city; the changes, shifts, breaks in the cloud helmet, movement of light on water. Drifting purposefully is the recommended mode, trampling asphalted earth in alert reverie, allowing the fiction of an underlying pattern to assert itself. To the no-bullshit materialist this sounds suspiciously like a fin de siècle decadence, a poetic of entropy—but the born-again flâneur is a stubborn 
creature, less interested in texture and fabric, eavesdropping on philosophical conversation pieces, than in noticing everything."

(Karen O'Rourke, Walking and Mapping: Artists as Cartographers. Cambridge MA and London: MIT Press, 2013: 25.)

"The 'road' cuts across accepted coordinates of space and time; for the figures live a priori in a reality with a dual foundation: in this world and, withal, in the upper worlds. For a brief moment the human is detached from earthly existence and passes over to survey the upper worlds with his body or his soul."

(David Greenstein, Roads to Utopia: The Walking Stories of the Zohar. Stanford, CA: Stanford University Press, 2014:12.)

“'Sorry, it isn't any good I'm afraid.' The Consul shut the door behind him and a small rain of plaster showered on his head. A Don Quixote fell from the wall. He picked up the sad straw knight..."

(Malcolm Lowry, Under the Volcano. Hammondsworth, Middlesex: Penguin, 1963: 95.)

"(I find myself defining threshold

As being the geometrical place

Of the comings and goings

In my Father's House.)"

(Michel Barrault, Dominicale, qtd. in Gaston Bachelard (Maria Jolas, Trans.), The Poetics of Space. Boston, MA: Beacon Press, 1994: 223.) 


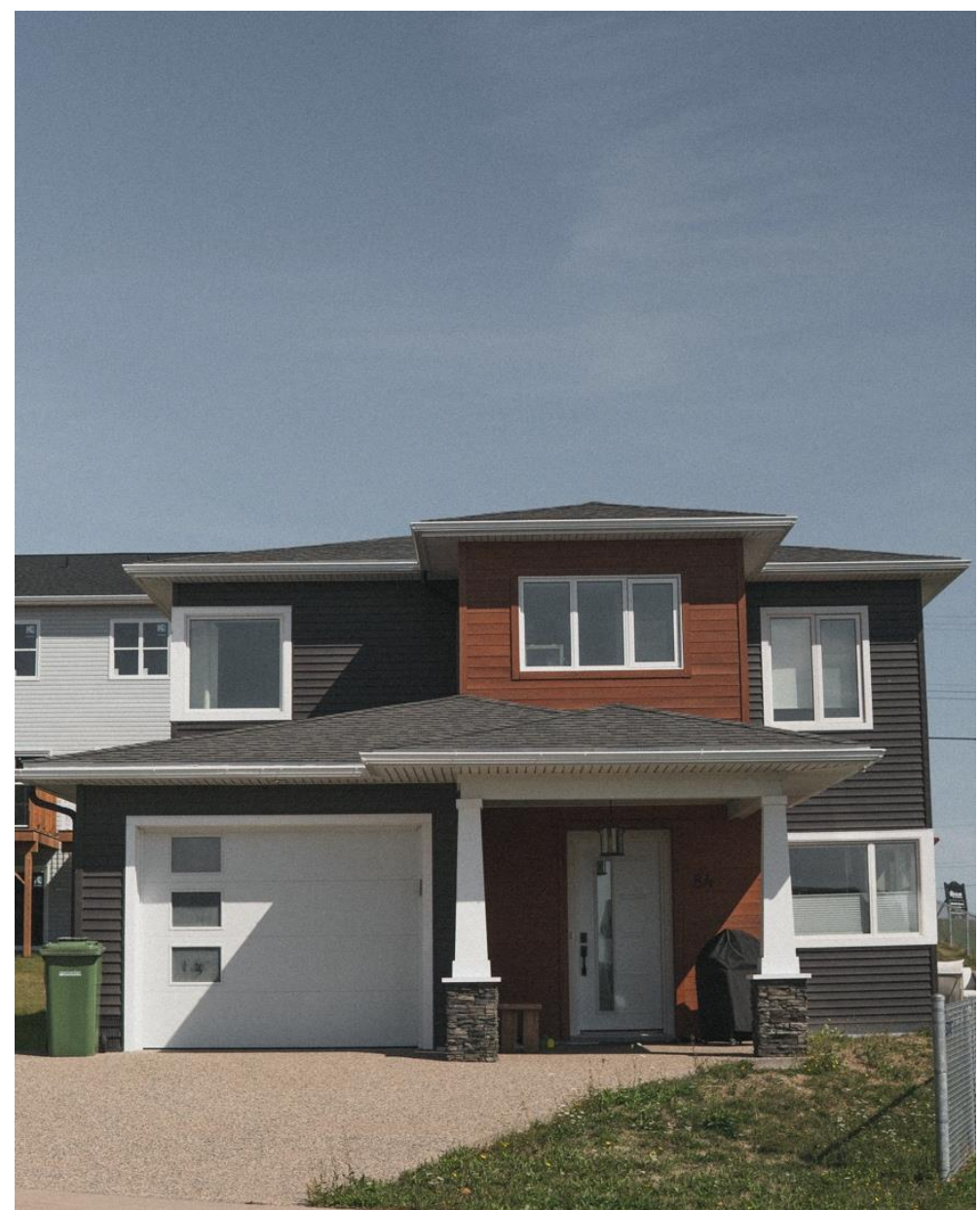

Geoffrey Howard, The Village at Long Lake, Halifax, Nova Scotia, Canada. (2020) Digital Photograph.

"The key to these new thresholds is the commodity, which, as understood by Marx, has both a use value and an exchange value. It might even be argued that the commodity itself is kind of a threshold: it stands at the point where use and exchange value meet. According to Benjamin, the commodity form is only just emerging in the early nineteenth century. It is itself on the threshold: 'the forces of production shattered the wish symbols of the previous century...' Similarly, Benjamin believed that his 
own era also stood at a threshold, the end of the commodity form: 'With the destabilizing of the market economy, we begin to recognize the monuments of the bourgeoisie as ruins even before they have crumbled."

(Peter Buse, Ken Hirschkop, Scott MacCracken, Bertrand Taith, Eds., Benjamin's Arcades: An Unguided Tour. Manchester and New York, NY: Manchester University Press, 2005: 54-55.)

"So resolutely turning her back upon the house, she set out once more down the path, determined to keep straight on till she got down the hill. For a few minutes all went well, and she was just saying, 'I really shall do it this time-' ' when the path gave a sudden twist and shook itself (as she described it afterwards), and the next moment she found herself actually walking in at the door."

(Lewis Carroll, "Through the Looking Glass," in Lewis Carroll: The Complete Works. London: CRW Publishing, 2005: 61.)

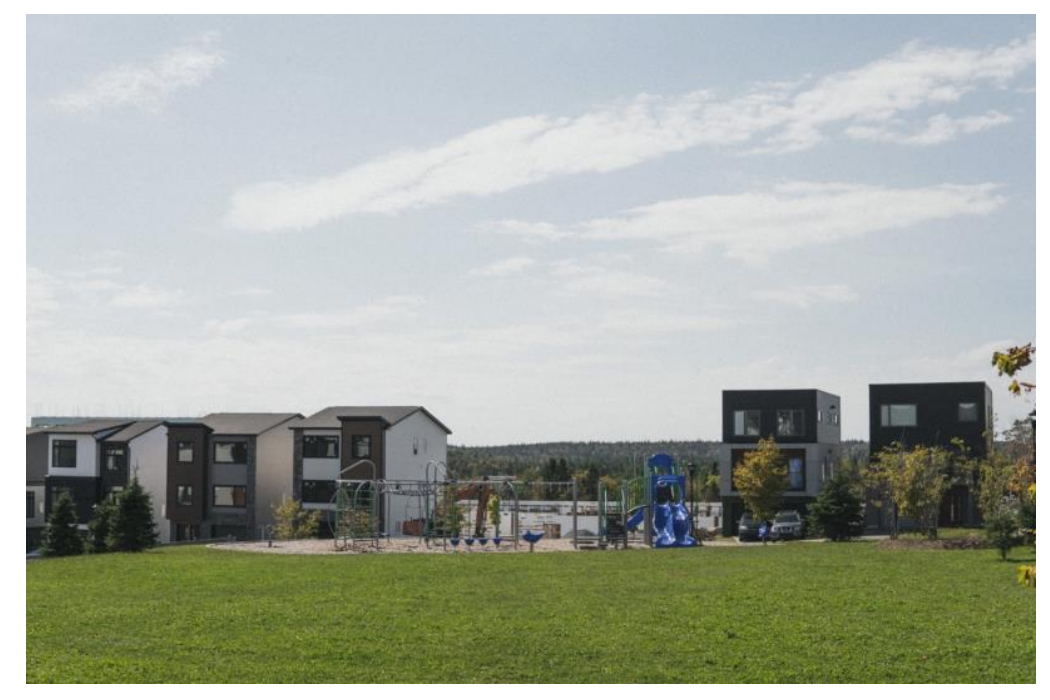

Geoffrey Howard, The Village at Long Lake, Halifax, Nova Scotia, Canada. (2020) Digital Photograph. 
“"We carry places with us,' gains a primordial significance greater than that indicated by habit alone. By carrying places with us, we open ourselves to a mode of embodiment that has less to do with habit and more to do with the continuity of one's sense of self. Such a mode of embodiment offers a more sustained and deeper commitment to the body's role as retriever of the past. Here, we are talking about not simply the mechanical repetition of routines, such that they orient us in an environment, but the very facticity of the world existing through the porous retention of our bodies."'

(Dylan Trigg, The Memory of Place: A Phenomenology of the Uncanny. Athens, Ohio: Ohio University Press, 2011: 11.)

"I am almost alone in the house. Through the sun-drenched walls I can see far, both right and left and down, the empty rooms suspended in the air, repeating themselves as in a mirror. And only on the bluish stairway, faintly sketched in by the sun, a lean, gray shadow is sliding up. I hear the steps now-and I see through the door-I feel the plaster smile glued to me. Then past my door, and down another stairway."

(Yevgeny Zamyatin (Mirra Ginsburg, Trans.), We. New York, NY: EOS, 1972: 108.)

"Today we have the capacity to turn the world into hell, and we are well on the way to doing so. We also have the capacity to turn it into the opposite of hell. This would mean the end of utopia, that is, the refutation of those ideas and theories that use the concept of utopia to denounce certain socio-historical possibilities. It can also be understood as the 'end of history' in the very precise sense that the new possibilities for a human society and its environments can no longer be thought of as continuations of the old, nor even as existing in the same historical continuum with them. Rather, they presuppose the qualitative difference between a free 
society and societies that are still unfree, which, according to Marx, makes all previous history only the prehistory of mankind."

(Herbert Marcuse, Five Lectures. Boston, MA: Beacon Press, 1970: 62.)

"Flesh is only the thermometer of becoming. The flesh is too tender. The second element is not so much bone or skeletal structure, as house or framework. The body blossoms in the house."

(Gilles Deleuze and Felix Guattari, What Is Philosophy? qtd. in Rosi Braidotti, Nomadic Theory: The Portable Rosi Braidotti. New York, NY: Columbia University Press, 2011: 162.)

"Memory is a central theme in Baudelaire's 'Le Peintre de la vie moderne' which, in making Constantin Guys the paradigm of an artist sensitive to 'modernité'- 'le transitoire, le fugitive, le contingent'- and to 'le fantastique reel de la vie', focuses at length on the creative process. Crucial to Baudelaire's account of Guy's art is the fact that although his aim is to capture the present he works from memory. Initially, Guy's technique is to plunge into the teeming diversity of the crowd:

The crowd is his domain, like air for birds, and water for fishes. His passion and profession are to become wedded with the crowd. For the perfect flâneur, the impassioned observer, it is an immense delight to make his home in the multiple, the undulating, in movement, in the fleeting and the infinite."

(Michael Sheringham, Everyday Life: Theories and Practices from Surrealism to the Present. Oxford: Oxford University Press, 2006: 62.)

"This tie between memory and place results in a difficult problem that takes shape at the crossroads of memory and history, which is also geography. This is the problem of the degree of originality of the 
phenomenon of dating, in parallel with localization. Dating and localization constitute in this respect solidary phenomena, testifying to the inseparable tie between the problematics of time and space. The problem is the following: up to what point can a phenomenology of dating and localization be constituted without borrowing from the objective knowledge of geometrical - let us say, Euclidean and Cartesian - space and from the objective knowledge of chronological time, itself articulated in terms of physical movement?"

(Paul Ricoeur (Translated by Kathleen Blamey \& David Pellauer), Memory, History, Forgetting. Chicago \& London: The University of Chicago Press, 2006: 41.)

"Adorno regards the 'effacement of memory' of the suffering as having certain roots in the conditions of German political and economic consciousness. Taking a Humboldtian line not commonly found in his work he argues that the overbearing state 'renders the majority of people dependent upon conditions beyond their control and thus maintains them in a state of political immaturity.' And Adorno specifies this 'immaturity' as the absence of 'autonomous subjectivity.' the ideal of German Idealism and eighteenth and nineteenth-century German liberal thought, the condition in which one might determine for oneself, in accordance with reason, what one ought to accept as true. The 'empty and cold feeling' is the action of those who 'would prefer to get rid of the obligation of autonomy."”

(Brian O'Connor, "Adorno and the Destruction of Memory," in Susannah Radstone and Bill Schwarz, Eds., Memory: Histories, Theories, Debates. New York, NY: Fordham University Press: 143.)

"For where there is history, there is also - and necessarily so, as Walter Benjamin so fruitfully argued - allegory. Allegory is a reflection on the ruins - the devastation, the dispersal, the noisy residue - that are 
themselves a seemingly interpretable remainder, partly of time per se, but also history's destructive power. If Baudelaire's streets, in their guise of 'fallen' rivers, are swollen with imminent revelation, then - a form of readability - it is not that they promise access to actual knowledge. It is rather that humanity's fall into history permits only the kind of frustrated recognition of our nonknowledge that composes the significance of allegorical thought. The word for such a recognition, which one might think of as the wisdom of the street, is, I suggest, disalienation - that is, the recognition of human alienation, something that is not the same as becoming in some miraculous way unalienated. Allegory, then can and does dispel illusion but it does so..., without installing in its place the possibility of knowing."

(Ross Chambers, An Atmospherics of the City: Baudelaire and the Poetics of Noise. New York, NY: Fordham University Press, 2015: 17.)

“'Fores...in liminibus profanarum aedium ianuae nominator,' Cicero noted: 'Doors are called the access points [ianuae] at the threshold of profane buildings.' The door is intimately connected to the notion of the threshold, a zone that belongs neither to the inside nor the outside and is thus an extremely dangerous place. The Romans saw the house door as dividing two worlds, 'the world outside, where there are innumerable hostile influences and powers, and the region within the limits of the house, the influences and powers of which are friendly.' Arnold van Gennep interprets crossing through doors and gates as a rite of passage: 'To cross the threshold is to unite oneself with a new world. It is thus an important act in marriage, adoption, ordination, and funeral ceremonies."'

(Bernhard Siegert (Geoffrey Winthrop-Young, Trans.), Cultural Techniques: Grids, Filters, Doors, and Other Articulations of the Real. New York, NY: Fordham University Press, 2015: 194-195.) 


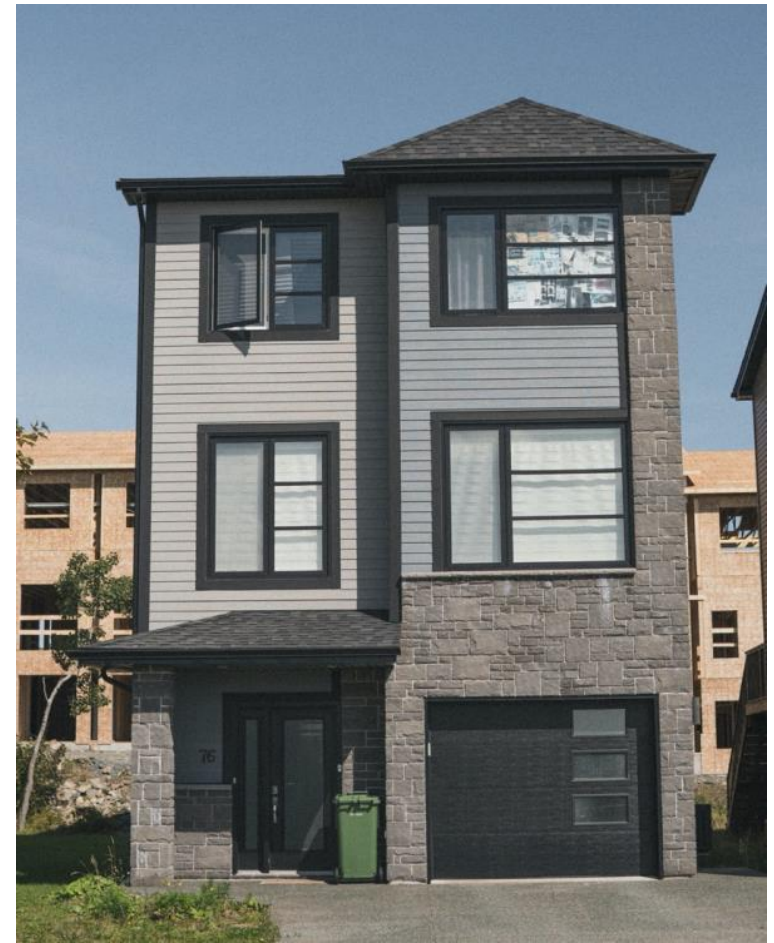

Geoffrey Howard, The Village at Long Lake, Halifax, Nova Scotia, Canada. (2020) Digital Photograph.

"To your sorrow you will see your palaces, which you have not raised with prudence to meet your needs but have thoughtlessly enlarged for your pleasures, fallen...fallen under the battering-ram or consumed by fire. You will see your populace, now a raging mob, disorganized and divided against itself, part for, part against you, soon united against you in howls of fury, since a starving mob can know no fear. You will see with remorse your churches, now thronged every day by crowds of your ladies, pillaged, and your children doomed to pay for their fathers' sins in bewilderment and ignorance. And if my prophetic soul is not deceived delivering a message brought home to me by unmistakable omens as well as by incontrovertible arguments, your small remnant, when the greater part has perished by slaughter or been taken prisoner, will witness with 
tears, before it passes into exile, the final delivery of your city, worn out with prolonged grief, into the hands of strangers."

(Dante, The Divine Comedy, qtd. in Melvin J. Lasky, Utopia and

Revolution: On the Origins of a Metaphor. Transaction Publishers, 2004:

24.)

"The House is humble and commodious. Here it is always fluent. Here we listen to voices. Here also are solid things. The House is a mould. The common division of the House is into three principal tiers-vegetal, sensitive, and rational. The souls inhabiting the House migrate among levels. The inferior may be alone, but the superior cannot subsist without the other. Let this epitome suffice: the rational cannot subside without the vegetal. The House is built from this complicated love really. Repeatedly we meet its surfaces. We see the House against the long scroll of politics, which is landscape, but also the House itself is a furled scroll. In the scroll of the House we are compelled to preserve what elsewhere we desire abolished."

(Lisa Robertson, "Report 1624: The House," in Lisa Robertson, Lisa Robertson's Magenta Soul Whip. Toronto: Coach House Books, 2009: 94.)

"The courage to go further down, down into the belly of the phantasmagoria without succumbing to it, is exactly what Benjamin's conspiracy calls for; it epitomizes the strategy of the antidote. Rather than looking 'up' for some external salvation, it looks down, toward the signs that serve as guides, havens, and a 'mighty paw' of resistance. The choice of 'going down' seems indeed quite awful until we realize that we are already stuck in the cave."

(James Martel, Textual Conspiracies: Walter Benjamin, Idolatry, and Political Theory. Ann Arbor, MI: University of Michigan Press, 2011: 258.) 


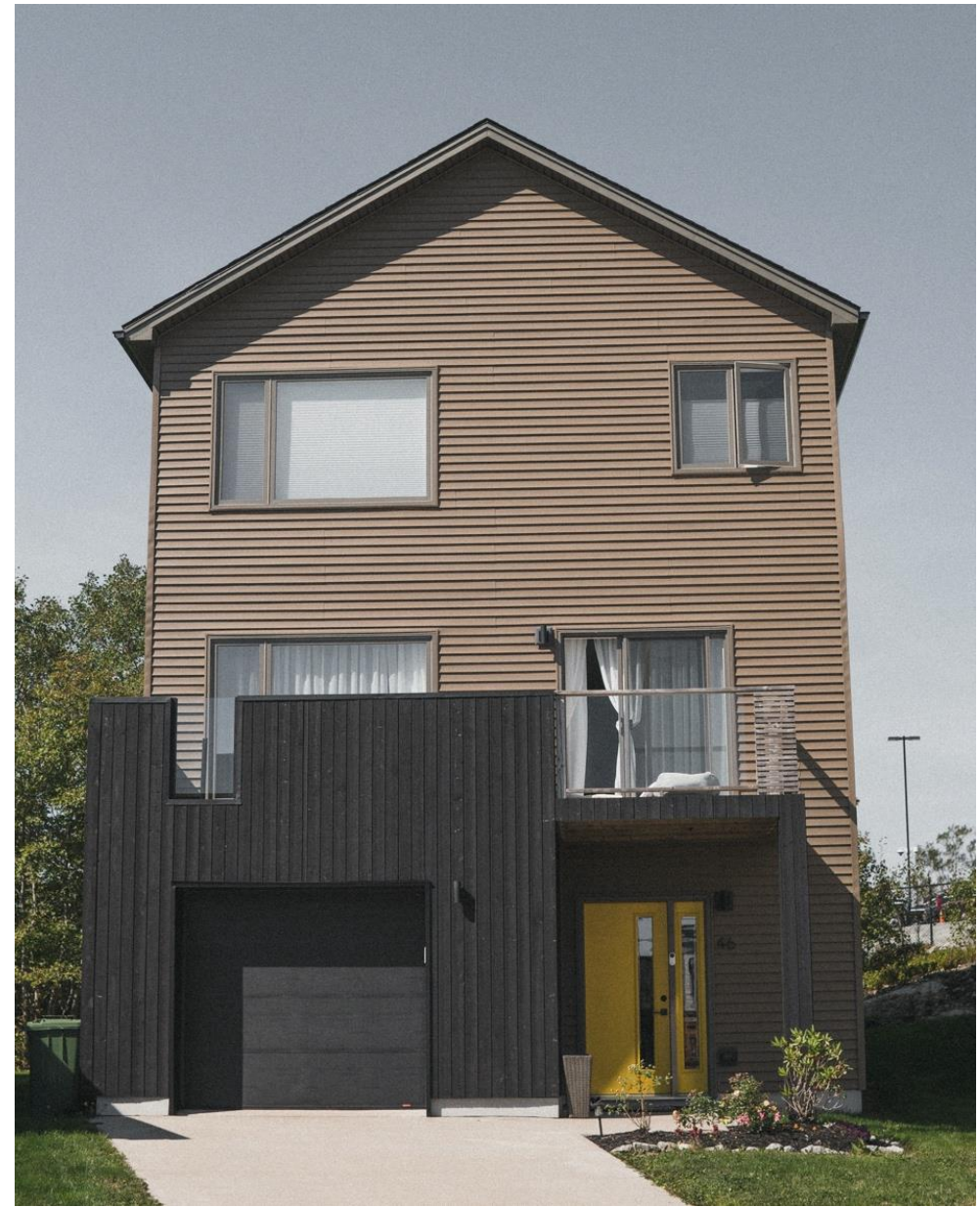

Geoffrey Howard, The Village at Long Lake, Halifax, Nova Scotia, Canada. (2020) Digital Photograph.

"On one side of this door lies Utopia and on the other the camps, in an antinomy of the modern that has since been forcibly resolved by collapsing the two into a single, double-wide norm: on the other side the global gated community and on the other the 'planets of slums.' These two sides of the new, urban coin-of-the-realm now effectively require one another, in what may seem like an infinite regress of negative-positive reproduction." 
(Rheinhold Martin, Utopia's Ghost: Architecture and Postmodernism Again. Minneapolis, MN: University of Minnesota Press, 2010: 24.)

"When the door opens, we'll scoot like cats to discover the future."

(Hélène Cixous, "From My Menagerie to My Philosophy," in Dorothea Olkowski, Ed., Resistance, Flight, Creation: Feminist Enactments of French Philosophy. Ithaca, NY: Cornell University Press, 2000: 46.)

"The sense of home slipping away provokes an unbearable yearning. The Portuguese have a name for this feeling: saudade, a word said to capture the homesickness and longing of separation from the homeland emigrants across the centuries. Now the disruptions of the twenty-first century have turned these exquisite anxieties and longings of dislocation into a universal story that engulfs each one of us."

(Shoshana Zuboff, The Age of Surveillance Capitalism: The Fight for a Human Future at the New Frontier of Power. Lebanon, IN: Hachette Book Group, 2020: 5.)

“...remains antinomously just what it always was."

(Frances Richard, Gordon Matta-Clark: Physical Poetics. Oakland, CA: University of California Press, 2019: 329.)

“...time's ruins build eternity's mansions..."

(James Joyce, Ulysses, in Christine Froula, Ed., Modernism's Body: Sex, Culture, Joyce. New York, NY: Columbia University Press, 1996: 128.) 
"Far from evolving unaffected by these powerful discourses of imperial and national historiographies, these private histories of home prove to be re-articulations of various grand narratives with the particular experience of domestic lives. It is by their necessary dependence on, and porosity for, dominant discourses that their status as entirely idiosyncratic accounts is disclaimed. The house/home, in other words, appears finally as a palimpsest in which a wide range of diachronically emitted interpellations are superimposed upon the other."

(Dirk Wiemann, Genres of Modernity: Contemporary Indian Novels in English (2008), in Eric D. Smith, Globalization, Utopia, and Postcolonial Science Fiction: New Maps of Hope. Houndsmills, Basingstoke, Hampshire: Palgrave Macmillan, 2012: 70.)

"[It] is... as if each new aggression from the cosmic exterior appeared at the same time as a disparity to be absorbed and as the perhaps unique opportunity to recommence, on the new grounds, the great totalityconcocting which tries to assimilate ancient and indestructible contradictions, that is, to surpass them in a unity which is at long last rigorous-unity which would be manifested as a cosmic determination... One may envisage the circular movement in a three-dimensional space, as a spiral whose many centers are ceaselessly deviated and ceaselessly rise by executing an indefinite number of revolutions around their starting point. Such is the personalizing evolution, at least up to the moment...of sclerosis or regressive involution. In this latter circumstance the movement indefinitely repeats itself by passing the same places again or else as an abrupt fall from a higher revolution to some inferior revolution."

(Jean-Paul Sartre, The Family Idiot: Vol. 1, in Edward Soja, Postmodern Geographies: The Reassertion of Space in Critical Social Theory.

London: Verso, 1989: 138.) 
"Our house floats like a small steamship, exhaling heat through the funnels.

It floats under the sky.

That's probably called 'drifting' in nautical language. The house drifts on the ground.

Nothing has been decided yet. The way hasn't been found.

My keys don't open all the doors of my era."

(Viktor Shklovsky, "On Architecture," in Viktor Shklovsky and Shushan Avagyan, Ed., A Hunt for Optimism. Dallas, TX: Dalkey Archive Press, 2013: 4.)

"We could say then that Dave, and many of his generation, grew up in two contexts at the same time: one is the actual 'real' world of his life in suburbia, the other a world made to seem more real, the fictional but much more entertaining and alluring world brought to them by television or other popular media. Their suburban life in fact was the ideal blank canvas on which to project or screen this fantasy world of fame, of unique, and glittering personalities, a possible life that was to be everything but average and anonymous. The cultural codes of the latter 'world' overwrote the codes of their suburban average lives, or they are at least juxtaposed with the rules and standards they have learned...."

(Nicoline Timmer, Do You Feel It Too? The Post-Postmodern Syndrome in American Fiction at the Turn of the Millenium. New York, NY and Amsterdam: Rodopi, 2010: 199.) 


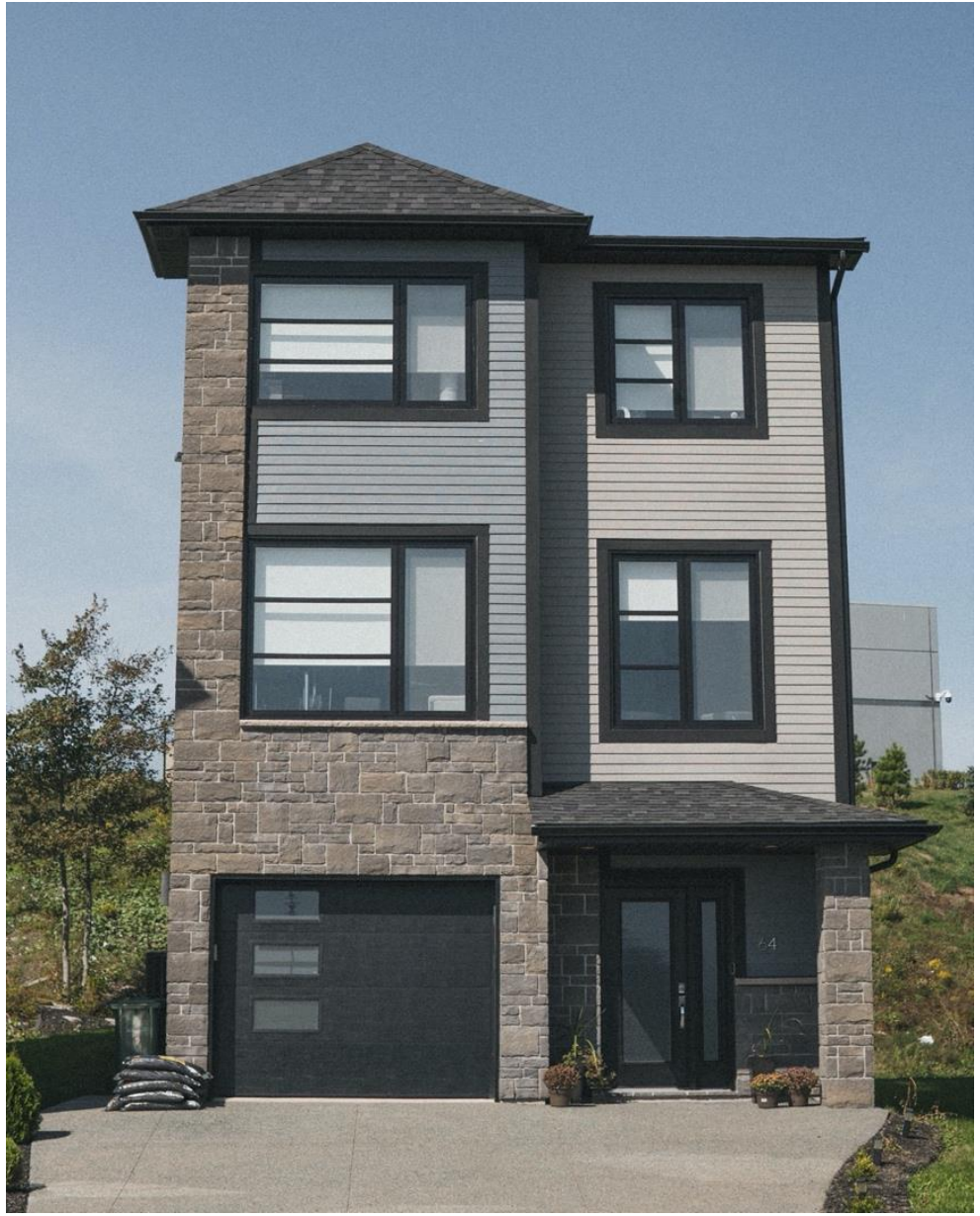

Geoffrey Howard, The Village at Long Lake, Halifax, Nova Scotia, Canada. (2020) Digital Photograph.

"The topographical force of the door lies in its capacity for movement: its paradox of belonging to two places at once. ..., such transformation, or passage, from one state to another was central to Duchamp's early art. But in his cubism, as well as the Large Glass, movement could only be represented through transitional moments of stasis. ...In its hinge-like shifts the door may open and close, but each move is contradicted: every 
opening is also a closing, and vice versa-movement is initiated only to be circumscribed."

(David Joselit, Infinite Regress: Marcel Duchamp 1910-1941. London and Cambridge: MIT Press, 2001: 169-171.)

\section{"Doorknob communication}

"All this interminable stalling and stoppage might suggest that the prospects of changes are bleak. And of course they are. But then again, it's only at moments of symbolic breakdown that history sheds its veneer as inexorable second nature. It is the experience of stuckness that forces us to reinvent the entire field."

(Rebecca Comay and Bart Zantvoort, Eds., Hegel and Resistance: History, Politics, and Dialectics. London and New York, NY:

Bloomsbury, 2018: 54.)

"When Rome imagined itself into becoming the centre of the world it did so from the centre of a web: 'if we were to make a symbolic map of the Roman world, its most conspicuous feature would be a centralized network of roads.' ... What marked out its successful advances also marked out the paths its downfall would take when power began to slip away, the retreats straggling armies and invaders would take and a gleaming target right there at the hub of the map. The centre moved elsewhere and has been moving since, even when the architects of civilisations try to turn it into stone."

(Darran Anderson, Imaginary Cities: A Tour of Dream Cities, Nightmare Cities, and Everywhere in Between. Chicago, IL: University of Chicago Press, 2017: 60.) 
"In upholding the principle of non-identity, the fundamental disjunction between concepts and objects, Adorno bases his mode of negative and immanent critique on tracing the cracks within 'the cellophane of modernity,' a deceptive sense of clarity within a society characterized by reified relations and the coercion resulting from the domination of nature. For Adorno, 'society's crystal-clear order' offers a promise of insight that fails to deliver anything more than ready-made enlightenment, blocking out a more engaging vision of change that is still to come. The urgent task of critical thought is to question the authenticity of that which might seem the most self-apparent and natural. This is a moment of resistance to a 'society of glass houses where every hiding place has been smoked out' and a departure from the belief that insight is to be found in the absence of mediation - the truth claim of the conventionally transparent - toward an examination of mediation itself."

(Eric Jarosinski, "Of Stones and Glass Houses: Minima Moralia as Critique of Transparency", qtd. in Gerhard Richter, Ed., Language Without Soil: Adorno and Late Philosophical Modernity. New York: Fordham University Press, 2010: 160.)

"Its always with another key that you unlock the door-inside."

(Paul Celan, "With a Key that Keeps Changing," in Paul Celan (David Young, Translator), From Threshold to Threshold. Gross Pointe Farms, MI: Marick Press, 2010: 55.)

"We write at a time there is an intensified and renewed awareness of the ruin and states of ruination. The eighteenth-century fascination with the ruin was closely linked to the emerging field of aesthetics, and its interest in sensory perception, the cultivation of human imagination and understanding, and the development of an appreciation for nature. Now everyone wants to get dirty with ruins. Whole subcultures of urban 
explorers are developing an alternative aesthetics based on direct engagement with decaying urban and quasi-urban terrains, with their own specialist subdivisions such as the bunkerologist, the place hacker, and the psychogeographer. Unlike their eighteenth and nineteenth century predecessors, urban explorers are not simply contemplating the ruin at a distance as an architectural artifact within a picturesque landscape composition or using it as a template for the architectures they create. These new ruinologists do not care for ruins sanctioned by good taste or compositional principles. They seek out the unloved and unremarked, the forgotten and derelict buildings. They break into, trespass, explore, photograph, video, and sound record. They report on buildings atmospheres and specters, their dangers and challenges, their atrophies and inertias..."

(Stephen Cairns and Jane M. Jacobs, Buildings Must Die: A Perverse View of Architecture. London and Cambridge, MA: The MIT Press, 2014: 182-3.)

"We shall not cease from exploration

And the end of all our exploring

Will be to arrive where we started

And know the place for the first time."

(T.S. Eliot, "Little Gidding," qtd. in Shlomith Rimmon-Kenan, Narrative Fiction. London and New York, NY: Methuen \& Co., 2003: 133.)

"Transparency came too early:

The open door, the wide-open window is threatening... The house might again become a fortress if not the catacombs. The wide window filled with a noisy outside needs an outside full of attractive strangers, not full of Nazis; the glass door down to the floor really presupposes sunshine that looks in and comes in, not the Gestapo." 
(Ernst Bloch, "Building in Empty Spaces" (1959), qtd. in Malcolm Miles, "Salvaging Modernism," in Malcolm Miles and Jennie Savage, Eds., Nutopia: A Critical View of Future Cities. Plymouth: University of Plymouth Press, 2012: 147.)

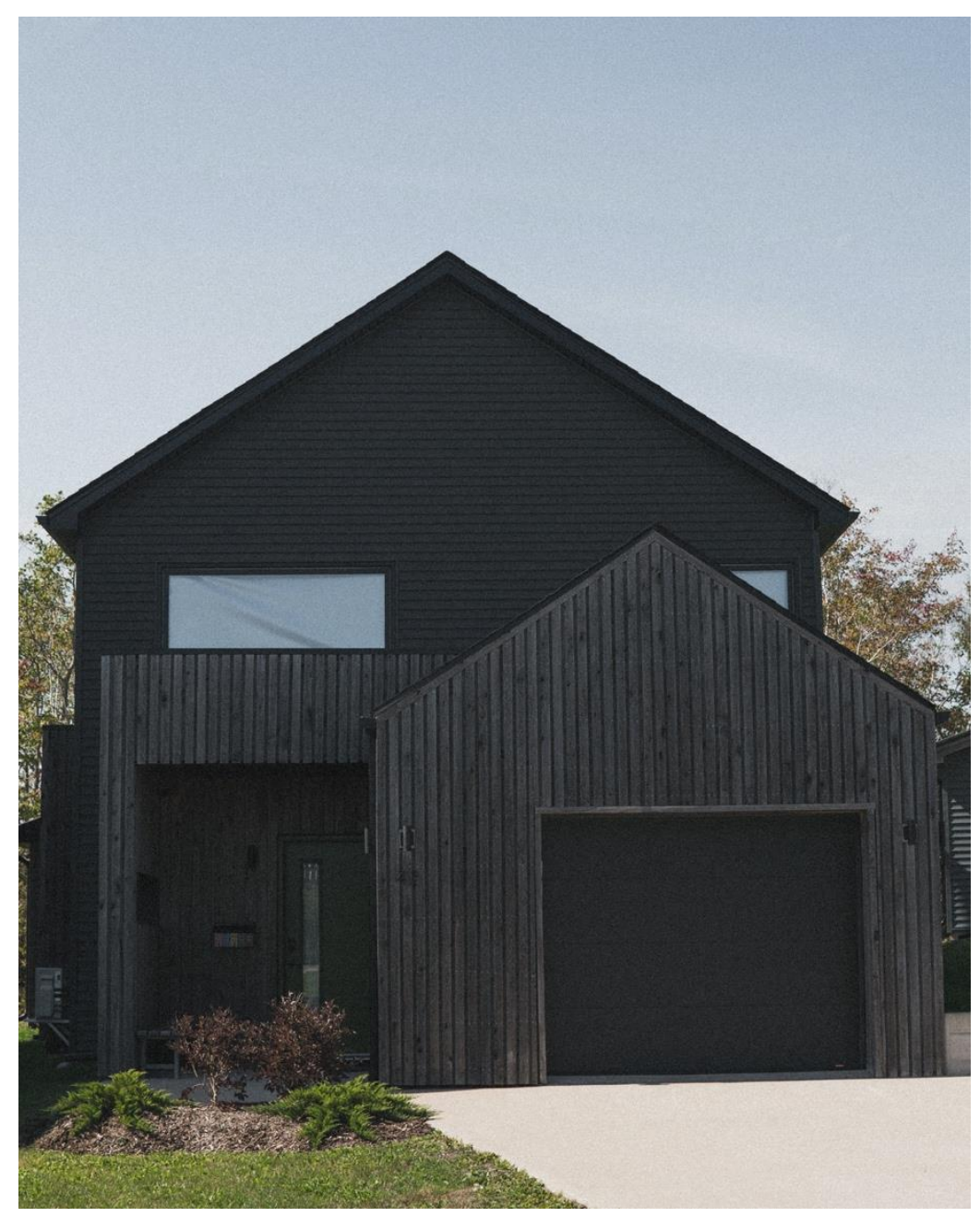

Geoffrey Howard, The Village at Long Lake, Halifax, Nova Scotia, Canada. (2020) Digital Photograph. 
"The house, grows darker. My first poem was 'Memory."”

(Rachel Blau Duplessis, "Memory," qtd. in Ann Vickery, "From Being Drafted to a Draft of Being: Rachel Blau DuPlessis and the Reconeptualisation of the Feminist Avant-Garde," in Louis Armand, Ed., Avant-Post: The Avant-Garde Under "Post-" Conditions. Prague, Czech Republic: Litteraria Pragnensia, 2006: 141.)

"That people could come into the world in a place they could not at first even name and had never known before; and that out of a nameless and unknown place they could grow and move around in it until its name they knew and called with love, and called it HOME, and put roots there and love others there; so that whenever they left this place they would sing homesick songs about it and write poems of yearning for it, like a lover..."

(William Goyen, House of Breath, qtd. in Ian Farr, Ed., Memory. Cambridge, MA: The MIT Press, 2012: 60.)

"Collection, Benjamin realized, is not merely about the assembly of things; it compensates for the perceived fragmentation of the collector himself. Its 'biological function' represents his own auto-circumscription. The collection, then, neutralizes the site-less-ness of de-contextualization, even while its act of assembly motors the very cycle of displacement in the first place. Even while it decontextualized the collection—or archive, which derives from the Greek term arkheion, meaning house or domicile - evinces 'an irrepressible desire to return to the origin, a homesickness, a nostalgia for the return to the most archaic place of absolute commencement,' notes Jacques Derrida. However, that said, Derrida points out that the archive is constituted by the inevitability of mnemonic loss. The death of memory, in other words, is both premise and consequence of archival desire. The collection organizes itself around the 
mutually informing conflict between memory and loss, between decontextualization and relocation, which identifies both the structural paradox of and homeopathic solution to homesickness."

(T.J. Demos, The Exiles of Marcel Duchamp. London and Cambridge, MA: MIT Press, 2007: 54-55.)

"...interior life (where the revolution always begins)."

(Pier Paolo Pasolini, "The Last Interview," in Smithers, "The Logic of the Martyr," in Black Box Collective, Eds., Black Box: A Record of the Catastrophe, Volume 1. Oakland, CA: PM Press, 2016: 25.)

"The poet Charles Baudelaire, writing in the middle of the nineteenth century with modernity in full swing, was one of the first to take note of the connections among evanescence, memory, and creativity. For Baudelaire, modernity was by definition inimical to the past; it assumed that for the new to achieve a secure footing, everything old and outworn had to be swept away. In the nineteenth century such an attitude often implied outright destruction of the past. Especially in 'progressive' circles in Europe, demolition was the preferred mode of dealing with outdated survivals, as was evident in Baron Haussmann's approach to the renovation of Paris in the 1850s and 1860s, which Baudelaire witnessed firsthand. As the premier urban planner of his day (or artiste-démolisseur as he preferred to call himself), Haussmann razed a large portion of vieux Paris in order to create a modern, streamlined capital city. In the course of doing so he not only tore down ancient buildings and ripped up old streets, squares, and passageways that had been part of the Parisian habitus for generations; he also abolished the long-standing personal and communal relationships existing in and around these sites. For those who experienced the shock of such transformations of the environment, the world began to look and feel quite different. As old stabilities and certainties were 
destroyed, life began to seem not anchored and dependable, but, as Baudelaire put it, increasingly 'ephemeral, fugitive, and contingent."'

(David Gross, Lost Time: On Remembering and Forgetting in Late

Modern Culture. Amherst, MA: University of Massachusetts Press, 2000: 144-145.)

"Here the labyrinth triggers not so much a path as a state of contemplation. Every turn proposes a new view of one's relation to the surroundings."

(Karen O'Rourke, Walking and Mapping: Artists as Cartographers. Cambridge, MA and London: MIT Press, 2013: 109.)

\begin{abstract}
"Alberti takes it as a given that 'the building is a form of body,' and he makes it clear that by 'body' he means a living body; 'the building', he writes, is in its entirety like a body composed of its 'parts'. He believes this analogy to hold both between bodies and individual buildings, and between bodies and cities; and the axiom permits him to introduce a new metaphor to guide spatial division, one which is organized around a central organ of privileged status analogous to the heart: the atrium of the house, the forum for the city. He presses the analogy further by distinguishing the supporting skeleton (ossia), the connective elements, nerves and ligaments (nervi, ligamenti) and the paneling (complementa), that is to say the infill and skin of the edifice."
\end{abstract}

(Paul Connerton, The Spirit of Mourning: History, Memory and the Body. London and New York, NY: Cambridge University Press, 2011: 45-46.)

"It is sometimes in the subtlety of the ordinary, in the interstices of domestic life that acts of appropriation or re-appropriation are effected, which, through their link with the body and the senses and through their more or less rigorous repetition, strongly mark the meaning of being 'at home'." 
(Jean-Paul Filiod, "Ça me lave la tête," Purifications et ressourcements dans l'univers domestique', qtd. in Michael Sheringham, Everyday Life: Theories and Practices from Surrealism to the Present. Oxford University Press, 2006: 302.)

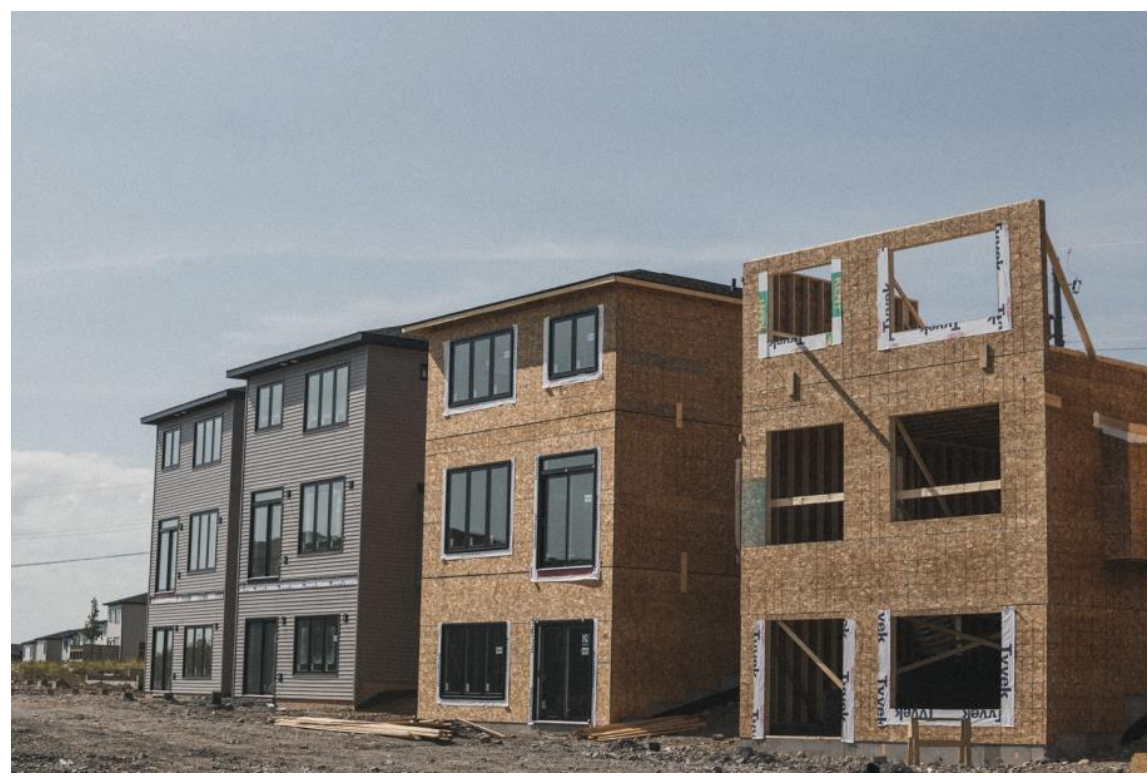

Geoffrey Howard, The Village at Long Lake, Halifax, Nova Scotia, Canada. (2020) Digital Photograph.

"The chamber of echoes again."

(Pierre Guyotat (Noura Wedell, Trans.), Coma. Cambridge MA and London: MIT Press, 2010: 216.)

"Only a rupture with the mode of subjectivation can secrete an existential crystallization productive of new references, and new self-positionings, which, in their turn, open the possibility for constructing new languages, new knowledges, new aesthetic practices, and new forms of life. To break 
with the dominant significations and the established forms of life, we must pass through points of nonsense, through the a-signifying and nondiscursive which in politics manifest themselves in the strike, revolt, or riot. The latter suspend time for a brief moment and create other possibilities from which, if they take on consistency, other subjectivations and existential crystallizations might proliferate."

(Maurizio Lazzarato (Joshua David Jordan, Trans.), Signs and Machines: Capitalism and the Production of Subjectivity. Cambridge, MA:

Semiotext(e), 2014: 223.)

"It is precisely that the idea of an end of history is inconceivable, except as a notion-limit, in other words, that it is essentially asymptotic, that motivates the incompatibility of historical times with the idea of Redemption. This idea, strictly considered, necessarily implies the completion of everything, the resolution of all contradictions, the end of the temporal continuum. Thus, it signifies a violent rupture of the historical fabric, the eruption into the heart of time of an absolute otherness, a form of experience radically different from everything we know. In this sense, Redemption is contrasted with utopia as a present event to an ideal end that is always postponed, as a stasis of time on an indefinitely extended line, as a sudden illumination at the endless series of moments."

(Stéphane Mosès (Barbara Harshav, Trans.), The Angel of History: Rosenzweig, Benjamin, Scholem. Stanford: Stanford University Press, 2009: 51.)

"Whilst bourgeois ideology projects history as a smooth linear continuum (Benjamin's 'empty, homogenous time'), the essential openness of the world-process is confirmed by the periodic irruption of the radically new into the apparently stable, what [Ernst] Bloch terms the novum, however fleeting or obscured, which negates the resistance to the new perpetrated 
by modes of static thinking, and it fuels what he terms the 'principle of hope'. Bloch posits that this 'latency of being-to-come' can be glimpsed most clearly in great art and literature (which explains his preoccupation with aesthetic questions), but also in a myriad of traces, signs and ciphers from fairy stories to architectural designs to advertising slogans as well as the reveries, dreams and fantasies that pervade all human societies."

(Michael E. Gardiner, Weak Messianism: Essay in Everyday Utopianism. Bern, Switzerland: Peter Lang, 2013: 71.)

"There are in French two words for 'future' which cannot be adequately rendered in English: futur and avenir. Futur stands for 'future' as the continuation of the present, as the full actualization of tendencies already in existence; while avenir points more towards a radical break, a discontinuity with the present-avenir is what is to come (a venir), not just what will be. Say, in today's apocalyptic global situation, the ultimate horizon of the future is what Jean-Pierre Dupuy calls the dystopian 'fixed point'; the zero-point of the ecological breakdown, of global economic and social chaos - even if it is indefinitely postponed, this zero-point is the virtual 'attractor' towards which our reality, left to itself, tends. The way to combat the catastrophe is through acts that interrupt this drifting towards the catastrophic 'fixed point' and take upon themselves the risk of giving birth to some radical Otherness 'to come.' We can see here how ambiguous the slogan 'no future' is: at a deeper level, it does not designate the closure, the impossibility of change, but what we should be striving for-to break the hold of the catastrophic 'future' and thereby open up a space for something New "to come."”

(Slavoj Žižek, The Year of Dreaming Dangerously. London and New York: Verso, 2012: 137.)

"What is unprecedented is not the loss of home but the impossibility of finding a new one. Suddenly, there was no place on earth where migrants 
could go without the severest restrictions, no country where they would be annihilated, no territory where they could found a new community of their own. This, moreover, had next to nothing to do with any material problem of overpopulation; it was a problem not of space but of political organization. Nobody had been aware that mankind, for so long a time considered under the image of a family of nations, had reached the state where whoever was thrown out of one of these tightly organized closed communities found himself thrown out of the family of nations altogether."

(Hannah Arendt, The Origins of Totalitarianism, qtd. in Simon Gikandi, "Between Roots and Routes: Cosmopolitanism and the Claims of Locality," in Janet Wilson, Cristina Şandru, and Sarah Lawson Welsh, Eds., Rerouting the Postcolonial: New Directions for the New Millennium. London and New York, NY: Routledge, 2010: 27.)

"Once there was a house! someone cries out; then, still breathing heavily, that person firmly exclaims: Once there was a house..., and finally manages to whisper (and can be heard, as the clamorous dissent dies away at last as though drifting off into other rooms): ... Once there was a house...built of water...

Have we heard this story before? If so, we have forgotten it."

(Robert Coover, "Playing House.” Iowa Review 35.2, 2005: 73.)

"Maybe it is a good thing for us to keep a few dreams of a house that that we shall live in later, always later, too much later, in fact, that we shall not have time to achieve it. For a house that was final, one that stood in symmetrical relation to the house we were born in, would lead to thoughts - serious, sad thoughts - and not to dreams. It is better to live in a state of impermanence than in one of finality."

(Gaston Bachelard (Maria Jolas, Trans.), The Poetics of Space. London and New York, NY: Penguin Books, 2014: 61.) 
"Philosophy that is still possible must be homeless, and dialectical thinking that is proper to deciphering historical suffering is deliberate exile from any alleged original or perfect philosophical language."

(Eduardo Mendieta, "The Jargon of Ontology," in Nathan Ross, Ed., The Aesthetic Ground of Critical Theory: New Readings of Benjamin and Adorno. London: Rowman \& Littlefield Publishers, 2015: 62.)

"...The similarity of one thing to another that we count on, that occupies us while awake, merely plays around the deeper similarity of the dreamworld in which what takes place never emerges as identical, but rather as similar, opaquely similar to itself... Torn by homesickness, he lay on his bed, homesickness for the world distorted in the state of similarity..."

(Walter Benjamin, "The Image of Proust," in Carol Jacobs, In the Language of Walter Benjamin. Baltimore and London: John Hopkins University Press, 2000: 101.)

"In Minima Moralia, Adorno quotes Nietzsche from the Gay Science, 'It is even part of my good fortune not to be a house-owner.' Then Adorno adds: 'Today we should have to add: it is part of morality not to be at home in one's home."”

(Eduardo Mendieta, "The Jargon of Ontology and the Critique of Language," in Nathan Ross, Ed.), The Aesthetic Ground of Critical Theory: 62.)

"In seeking relations of attachment and security amid alterity, we are all unhoused - which is the condition of possibility through which we recognize the need for universal welcome." 
(Matt Waggoner, Unhoused: Adorno and the Problem of Dwelling. New York, NY: Columbia Books on Architecture and the City, 2018: 44.)

"Does one dwell and depart simultaneously...?"

(Robert Gibbs, "Messianic Epistemology," in Yvonne Sherwood and Kevin Hart, Eds., Derrida and Religion: Other Testaments. New York, NY and Milton Park, Abingdon: Routledge, 2005: 122.)

"This brings us to the most important question: to what extent does this moment of inertia in social-historical development really contradict the traditional view of Hegelian dialectics as an unstoppable progressive development which overcomes all resistance and integrates all differences? Isn't the obsolete persistence of an antiquated structure, which Hegel clearly describes as a possibility, merely a contingent moment which is, as Hegel puts it in the Phenomenology, has to start its development from the beginning, but at a higher level."

(Bart Zantvoort, "Unthinking Inertia," in Rebecca Comay and Bart Zantvoort, Eds., Hegel and Resistance. London and New York, NY: Bloomsbury, 2018: 127.)

"This door has no name on it, and nobody..., has seen it open or knows what there is behind it. There it is, a door, and it does nothing but gather dust and cobwebs and occasionally drop another flake of dried paint on the worn step below. Perhaps it leads into another world. Perhaps it will open, one morning, to admit an angel, [who], after looking up and down the little street for a moment, will suddenly blow the last trumpet."

(Theodor W. Adorno, "The Economic Crisis as Idyll," in Theodor W. Adorno (Rolf Tiedemann and Paul Kottman, Eds., and Sherry Weber 
Nicholson, Trans.), Notes to Literature, Volume Two. New York:

Columbia University Press, 1994: 285.)

"The courage to go further down, down into the belly of the phantasmagoria without succumbing to it, is exactly what Benjamin's conspiracy calls for; it epitomizes the strategy of the antidote. Rather than looking 'up' toward some external salvation, it looks down, toward the signs that serve as guides, havens, and a 'mighty paw' of resistance. The choice of 'going down' seems quite awful until we realize that we are already stuck in the cave. We are, not unlike Socrates' cave dwellers, trapped in a world of delusions. But in this case, rather than go out to see the sun (the ultimate delusion, perhaps), we have to burrow deeper into the recess of the cave. If we have no choice but to go deeper, let us go together, fighting and resisting every step of the way. We may, indeed must, have no hope, but in that hopelessness we can, just maybe, fight to see another day."

(Martel, Textual Conspiracies: 258.)

"Here it comes, I said to myself, the end is coming; something is happening, the end is beginning. I was seized by joy.

I went to the house but did not enter."

(Maurice Blanchot, The Madness of the Day. Barrytown, NY: Station Hill Press, 1995: 10.) 